\title{
The first towns in the central Sahara
}

\author{
D. J. Mattingly \& M. Sterry*
}

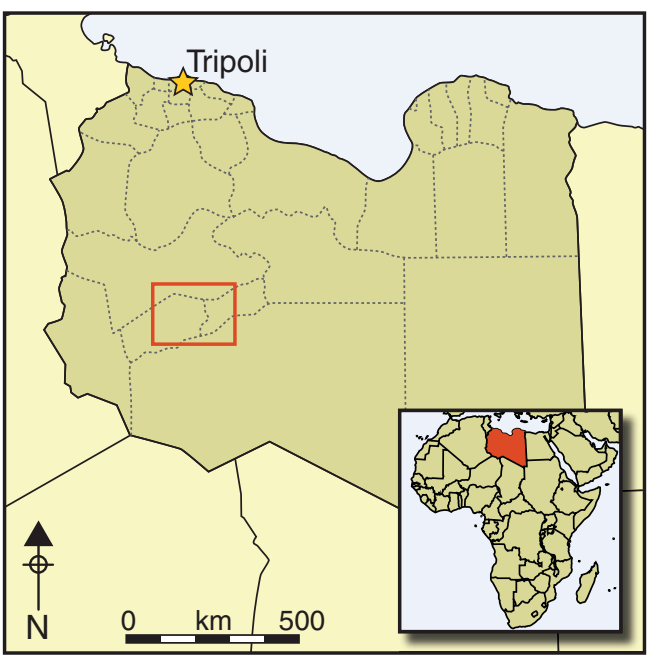

At first sight Saharan oases appear unlikely locations for the development of early urban communities. Recent survey work has, however, discovered evidence for complex settlements of the late first millennium $B C$ and early first millennium $A D$, surrounded and supported by intensive agricultural zones. These settlements, despite their relatively modest size, satisfy the criteria to be considered as towns. The argument presented here not only presents the evidence for their urban status but also argues that it was not agriculture but trade that conjured them into existence. Without the development of trans-Saharan trade, these complex oasis communities would have been unsustainable, and their subsequent economic fortunes were directly linked to the fluctuating scale and direction of that trade.

Keywords: Libya, Fazzan, Old Jarma, Garamantes, urbanism, towns, trans-Saharan trade, irrigation

\section{Introduction}

Towns or cities are a defining characteristic of most complex polities. A multitude of definitions have been put forward, some favouring checklists of urban traits (most importantly Childe 1950; cf. Talbert 2000; M. Smith 2003; M.E. Smith 2009), others emphasising the roles of towns within landscapes and people's lives (Yoffee 2005), some contrasting rural and urban identities (Cowgill 2004) and some that dismiss the idea that there are defining features (A.T. Smith 2003). Of particular importance has been work in sub-Saharan Africa that has introduced ideas of towns as agglomerations and heterarchy (S. McIntosh 1999; R.J. McIntosh 2005). There is, however, increasing awareness that urban societies are not an inevitability, but one of many variations, with versions distinct to their ecologies. To investigate these requires substantial exploration and, most likely, excavation of both the urban centre and its hinterland.

There are still regions of the world and periods of time where this baseline of knowledge is just being reached, with new additions to the list of societies diagnosed as urbanised. More

\section{School of Archaeology and Ancient History, University of Leicester, University Road, Leicester LE1 7RH, UK}


useful in these cases is Yoffee's view that cities were "supernova" that re-routed and utterly changed patterns of everyday life, creating new landscapes of urban-rural interactions (2005: 61-62; contra Morley 2011: 151). A search for cities in archaeologically blank parts of the world must therefore look for settlements that are distinct from all other settlement forms, generative of new forms of social life, and that show clear evidence of interactions with a hinterland.

The aim of this paper is to demonstrate that within the Libyan Sahara, before the historical expansion of trans-Saharan trade in the Islamic period, there existed a remarkable system of settlements supported by intensive oasis agriculture. Within this system there was a small number of large and distinct sites that should be considered as urban. This has significance both in the context of debates about Saharan states and the urbanisation of neighbouring areas of Roman and sub-Saharan Africa.

\section{Urbanisation in the Sahara}

The archaeology of Saharan oases remains poorly documented and the assumption has tended to be that they were settled primarily in the Islamic era (Lydon 2009; Austen 2010). A major result of recent fieldwork in Libya has been the demonstration that many oases supported sedentary populations as early as classical antiquity (Mattingly \& MacDonald 2013).

Early urbanisation is well-documented in surrounding areas (Mattingly \& MacDonald 2013). Along the Nile the first cities emerged from the late fourth millennium BC, and by the first millennium BC can be traced as far south as the kingdom of Meroe. Along the north African coastline in the first millennium BC, the Phoenicians and Greeks established a string of colonies. There were also early urban developments in the indigenous kingdoms of Numidia and Mauretania. In sub-Saharan Africa the cities of the Middle Niger date back at least to $400 \mathrm{BC}$ and this date may yet be pushed back further (McIntosh 2005). In the Sahara itself little evidence has hitherto been recognised for pre-Islamic cities. However, along its northern edge in Tunisia, Algeria and Libya there were oasis centres that received Roman garrisons or attained urban status under Rome. The Saharan interior is largely unknown due to a lack of archaeological investigation within the oases, but this picture is changing, at least within central Libya.

The Garamantes were a Libyan people known to Greco-Roman writers (Mattingly 2003). Their heyday appears to have been in the period $300 \mathrm{BC}$ to AD 500, but their overall rise and decline spans the first millennia BC/AD. Sources speak of a kingdom, and archaeological evidence suggests that at their greatest power they controlled an area of the central Sahara covering around $250000 \mathrm{~km}^{2}$ (Figure 1). Although the classical writers were generally dismissive about their capacity, archaeological evidence shows that the Garamantes were a sophisticated civilisation practising advanced irrigated oasis agriculture from early in the first millennium BC. Initially, this irrigation relied probably on a combination of artesian springs and shaduf wells, a water lifting technology that was likely obtained from Egypt. From the later first millennium BC, foggaras or qanats proliferated in several parts of Fazzan. These were underground galleries tapping groundwater and leading it to the surface hundreds or thousands of metres away (Wilson \& Mattingly 2003). The Garamantian capital at Old

(C) Antiquity Publications Ltd. 




Figure 1. Location map showing Fazzan and sites mentioned in the text. Image data (c) Esri.

Jarma (ancient Garama) has long been seen as potentially exceptional, described by Ptolemy (Geography 4.6.12; Berggren \& Jones 2000) as a metropolis and by Pliny (Natural History 5.35; Rackham 1938) as their 'celebrated' centre. Since the 1960s, stone-footed buildings have been known, incorporating elements of classical architecture (Ayoub 1967), and finds from Jarma provide the key evidence in a long-running debate about the extent of preIslamic Saharan trade (Mattingly 2003). Our recent fieldwork has now revealed a plethora of other Garamantian settlement sites, primarily of village scale and commonly located less than $1 \mathrm{~km}$ apart throughout the linear oasis bands of Fazzan.

The case for the Garamantes as an urban society (Mattingly 2003, 2006) has been based primarily on excavations at Jarma and settlement survey in the Wadi al-Ajal. However, the presence of overlying settlement at Jarma and the masking effect of modern oasis agriculture have prevented hitherto all but the most schematic of reconstructions of the settlement system. While the impressive number of settlements recorded has necessitated upward revision of the population density of Fazzan in antiquity, the nature of the society has remained an open question.

Fieldwork has recently been extended to the Wadi Utba and the Murzuq depression, where modern settlement overlaps less with ancient sites. Using satellite imagery and aerial photography, we have mapped extensive zones of settlements, cemeteries, field systems, irrigation works and trackways (Sterry \& Mattingly 2011 for preliminary summary). We

(C) Antiquity Publications Ltd. 
have so far mapped 158 new settlements, 184 cemeteries and $30 \mathrm{~km}^{2}$ of fields. But can any of these sites be considered to be towns?

The 'town' classification is important for three reasons:

1. Despite some calls to the contrary, towns continue to be seen by the wider archaeological community as key evidence of statehood and social complexity. The urban criterion is thus of crucial importance to understanding the nature of Garamantian society.

2. The presence of towns implies that a part of the population was involved in non-agricultural production, for instance as craft specialists. Was this true of the largest Garamantian sites?

3. Towns have often been taken as a proxy for higher level economic development. In the Sahara, the presence of Islamic towns has historically been intimately linked to transSaharan trade. Their existence in pre-Islamic times therefore suggests the conditions for trans-Saharan trade, if not in fact directly evidencing such activity.

\section{Old Jarma}

The urban credentials of Old Jarma thus far have rested on several significant characteristics - specifically size, monumentality, non-agricultural specialisation and its status as a focus for economic, religious and political power. The overall size of the Garamantian site is difficult to confirm as it is overlain by a sequence of Islamic settlements within a walled circuit enclosing around 9.3ha. The observed distribution of dressed-stone blocks in the foundations of later buildings suggest that it was at least 7.5 ha (Figure 2 ). The 1997-2001 Fazzan Project excavations yielded evidence for specialised metalworking and large-scale carnelian working at the site (Mattingly forthcoming). Its focal nature is illustrated by its status as the centre of royal authority (Ptolemy's Geography 1.8 [Berggren \& Jones 2000] specifically links Jarma with Garamantian kings), by the identification of temples and by the abundant imported materials that show that it was a trade hub. During the Late Garamantian period a substantial fortified compound was built in the central area and there is a hint of a Garamantian predecessor to the medieval defences. Survey in the modern oasis around Jarma has revealed numerous other ancient sites although their character and size are unclear in most cases, owing to the effects of more recent agriculture and settlement (Figure 3). Two sites, Saniat Jibril and Saniat Sulayman Krayda, have been investigated in more detail (Mattingly 2010); these were open villages of a few hectares. Jarma seems a credible candidate for urban status, but the possibility that it was a unique metropolitan centre needs to be considered before we can ascribe an urban character to Garamantian society more broadly. Although we lack sufficient excavation at most other sites, survey observations of size and activity can be assessed. These demonstrate that Jarma was not exceptional but that there were other pre-Islamic sites of comparable size and complexity.

\section{Qasr ash-Sharraba}

This site was first recorded by Charles Daniels in 1968 (though he interpreted it as Islamic; Daniels 1989), and revisited in 1999-2000 by the Fazzan Project (Mattingly 2007). It is substantial in size, with around 15 ha of rectilinear buildings (Figure 4) and several square

(C) Antiquity Publications Ltd. 


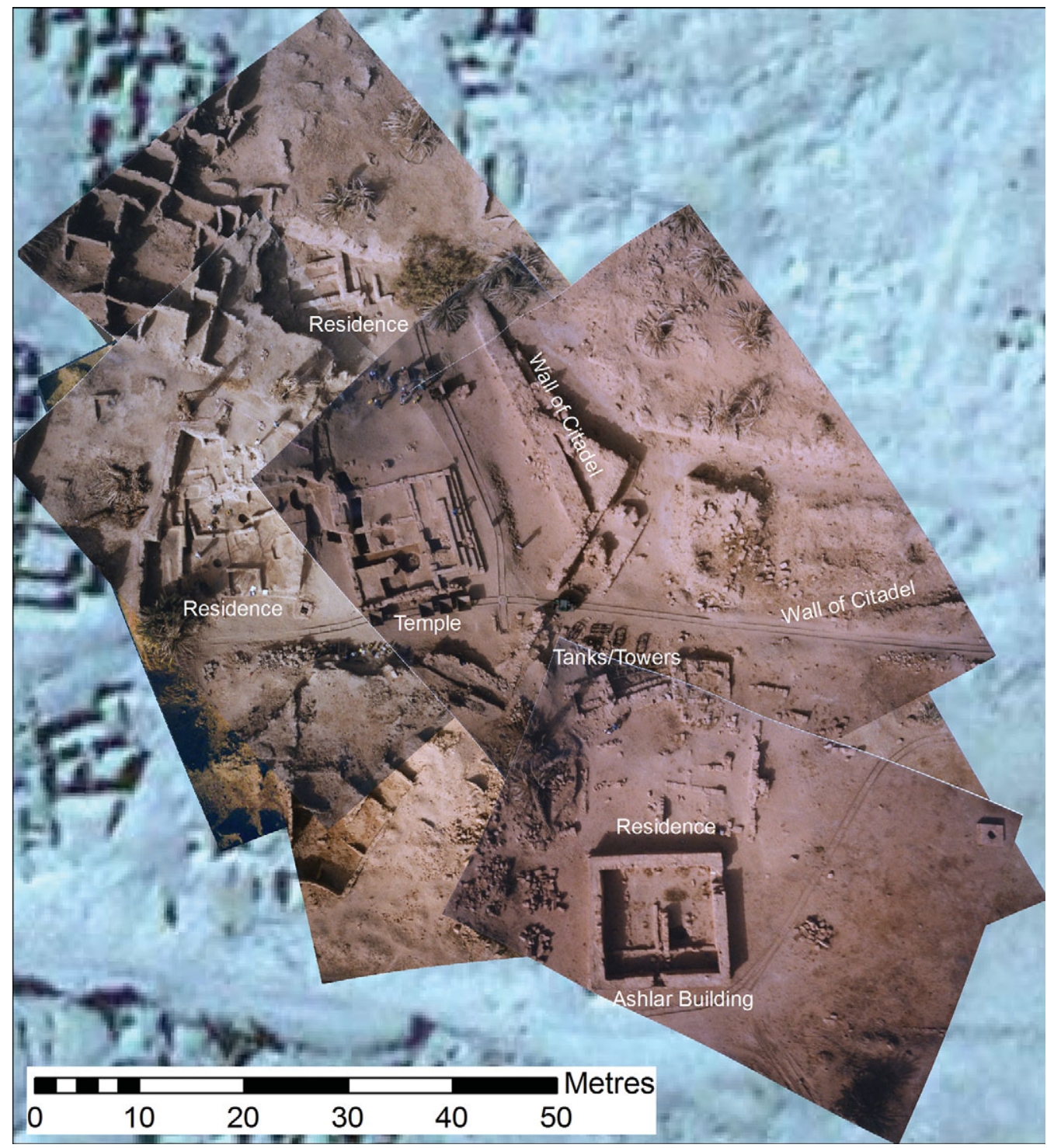

Figure 2. Rectified kite images of the monumental buildings excavated at Jarma.

kilometres of field systems. There were two fortified buildings (qsur) in the settlement, one lying within a large fortified compound and two further qsur amongst the extensive fields or gardens that surrounded the settlement. The central area of the town was partially surveyed in 2000 , but a complete plan was not possible at that time.

Surface finds included relatively numerous Roman-period amphorae and fine wares, with a few sherds that may be Islamic. Three AMS samples from the mudbrick fabric and a stratified sequence exposed within the fortress qasr provided ${ }^{14} \mathrm{C}$ dates of cal AD 230-420, cal AD 560-660 and cal AD 1020-1220 (Mattingly 2007: 296-97).

(C) Antiquity Publications Ltd. 


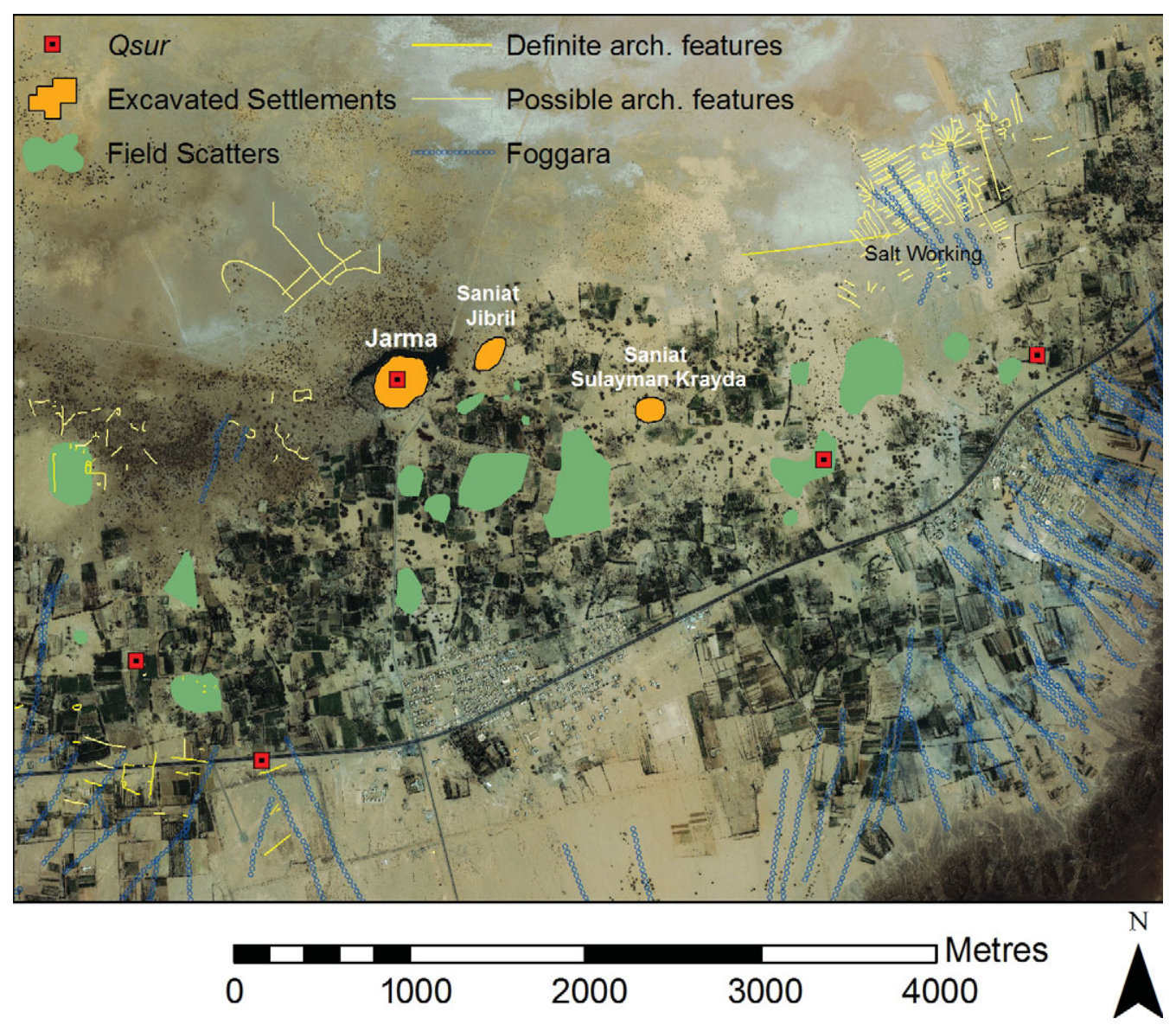

Figure 3. 2002 Ikonos-2 image of the reconstructed hinterland of Jarma.

Satellite image analysis has allowed the site to be reassessed and a complete plan to be drawn for the first time (Figure $4 \mathrm{a}-\mathrm{c}$ ). It is clear that there was no overall enceinte wall, security being provided by the central fort and the two qsur. Directly beyond the built-up area the gardens began, so the oasis cultivation may in itself have defined the edge of the site. We can now confirm that the built-up area measured between 15 and 18ha, though windblown sand obscures some sectors. The settlement seems to have consisted of several districts arranged around the fort, with the south-west district containing its own small qasr. Most buildings seem to have been built from a mixture of mudbrick and small stones. The districts are linked by a series of streets, the longest of them running through the length of the settlement from east to west, leading to a central open space just south of the fort. It can also be traced eastward into the gardens for up to $2 \mathrm{~km}$. Many building walls and streets or alleyways run off the main east-west road at roughly perpendicular angles, giving the site an overall planned appearance. This layout is strikingly different to the more irregular arrangements visible on earlier escarpment sites and at peripheral 'Garamantian' sites such as Aghram Nadarif near Ghat, which had much less regular layouts and less complex buildings (Liverani 2006; Mattingly 2010).

(C) Antiquity Publications Ltd. 


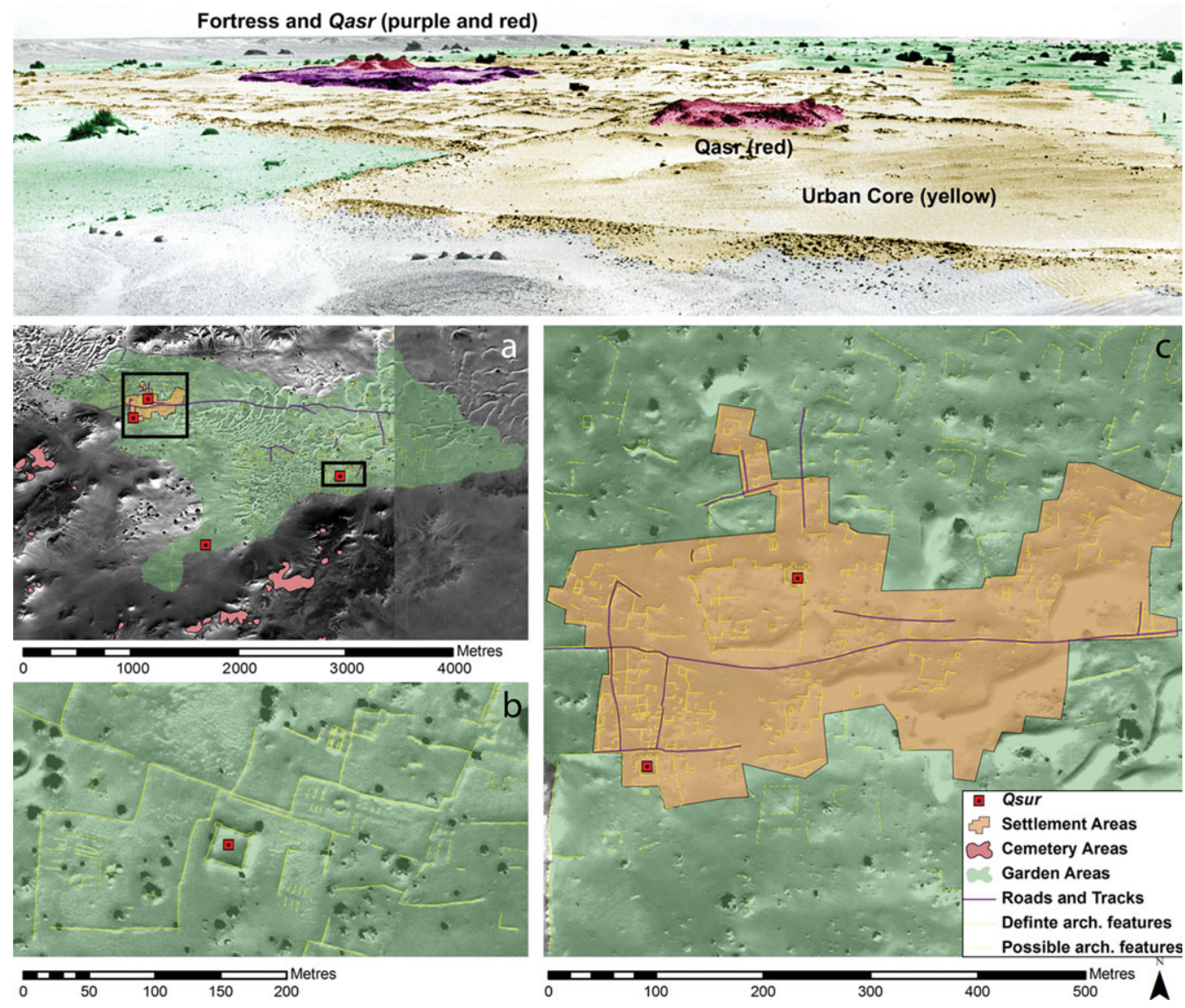

Figure 4. Qasr ash-Sharraba: top: merged photographs of the urban core; bottom: 2002 Ikonos-2 image and 1958 aerial photograph of a) the extent of the hinterland; b) outlying qasr and gardens; c) the urban core.

Three sides of the central fort are well preserved, with projecting rectangular corner and interval towers, and a probable barbican entrance on the northern side. The fort encloses an area of 0.7 ha and is reminiscent of a number of sites found to the east of Murzuq (Sterry \& Mattingly 2011: e.g. sites ZZW014, ZZW016, GAT010) which consist of a central qasr surrounded by a walled settlement. A key distinction at ash-Sharraba is that the overall settlement area far exceeded the core walled enclosure. Built into the north-eastern corner of the fort is a small qasr $\left(300 \mathrm{~m}^{2}\right)$. A similar qasr with an area of $270 \mathrm{~m}^{2}$ is located $115 \mathrm{~m}$ to the south-west of the fort. Buildings in the rest of the settlement are much harder to identify due to overlying windblown sand, but were undoubtedly rectilinear in plan.

There are two qsur on the southern edge of the field system around Qasr ash-Sharraba. These are somewhat larger than the two inside the settlement $\left(700 \mathrm{~m}^{2}\right.$ and $\left.1400 \mathrm{~m}^{2}\right)$, are square in shape with corner towers and are on the same alignment as the adjacent gardens. A number of other buildings are scattered throughout the field system in ones and twos, most evidently in the eastern half, where there is less overlying sand.

(C) Antiquity Publications Ltd. 
The field system that must have supplied Qasr ash-Sharraba covered a total of 556ha, comprising around 1600 gardens based on the measureable areas ranging between 0.2 and 1ha per garden (average $0.35 \mathrm{ha}$ ).

A further notable element of the Qasr ash-Sharraba environs is the presence of 47 cairn cemeteries (covering 26.9ha) perched on the low hills that surround the cultivated area and settlement. These cemeteries were pre-Islamic in form and eight yielded surface sherds of amphorae and other Mediterranean wheel-made ceramics of the first four centuries AD.

Qasr ash-Sharraba thus provides a second compelling example of a Garamantian urban centre and opens the possibility that urban centres were a feature of other pre-Islamic oasis societies in the Sahara.

\section{Other large Garamantian settlements}

We have identified two other sites that stand out for the extent and preservation of their remains and help to put Qasr ash-Sharraba in context (for sites mentioned below, see Sterry \& Mattingly 2011; see Sterry et al. 2012 for the AMS dates).

\section{HHG001}

This $c$. 3ha site is enclosed within a trapezoidal enceinte, focused on a central qasr with large towers (Figure 5). An AMS date from one of the corner towers, along with imported Roman ceramics, dates the site to the fifth-sixth centuries AD. The outer enceinte had rectangular corner towers and three intermediate towers on each side. The internal structure is complicated, but seems to be composed of four distinct compounds or clusters of houses with a number of polygonal enclosures attached to them; these loosely correspond to the four corners of the enceinte. There is no clear street network, though a main access route from the east gate leads to an open area in front of the moat surrounding the central qasr. The perpendicular arrangement nonetheless implies a degree of planning and a desired rectilinear shape. In plan, the internal buildings more closely resemble the plans of other nearby but smaller fortified settlements (sites ZZW014, ZZW016, GAT001, GAT012, LGR099). Fragments of mudbrick walls $100 \mathrm{~m}$ to the south of the settlement and sandedup wells to the east suggest that a field system of at least 25 ha was attached to this settlement. Although quite a large fortified site, the population that could be sustained on the available gardens would be no more than a few hundred. HHG001 seems to fall into a different category to Qasr ash-Sharraba.

\section{HHG006-008}

This site is composed of three qsur, HHG006, HHG007 and HHG008 (each with corner towers and a moat), that are linked by regular blocks of rectangular mudbrick houses similar to those found at the other sites discussed. The agglomeration covers around 5 ha although with several large open spaces within (Figure 6). In plan it resembles Qasr ash-Sharraba, as it consists of districts of houses with HHG006 in the centre, HHG007 to the west (C) Antiquity Publications Ltd. 


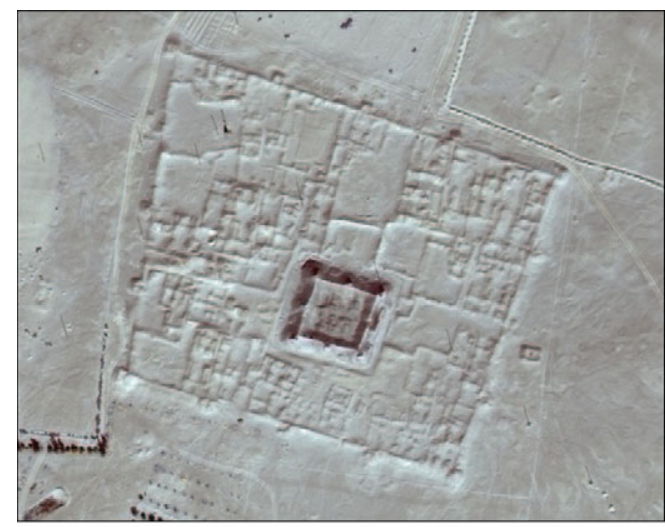

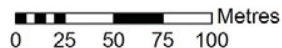

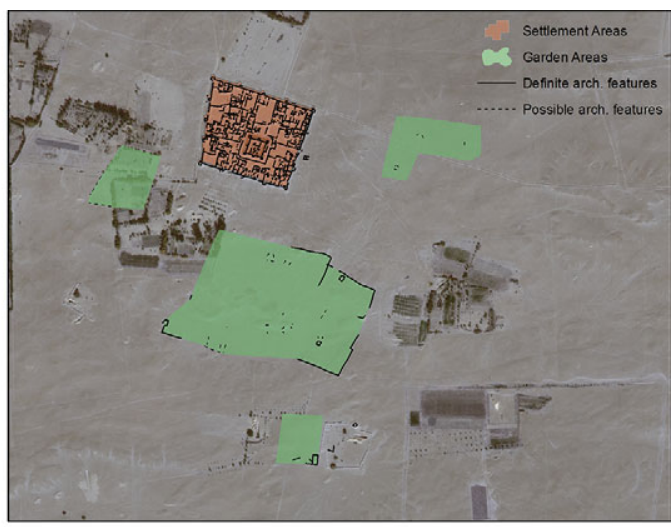

M Metres

Figure 5. 2011 WorldView-2 image of HHG001: left) detail of the settlement; right) archaeological features in the vicinity.

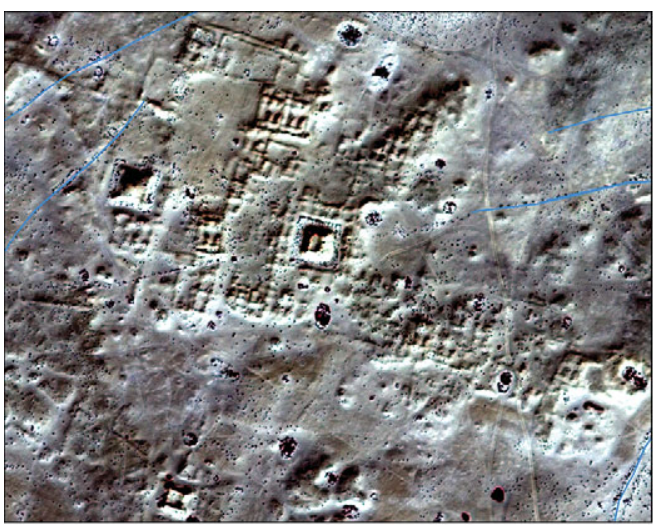

0
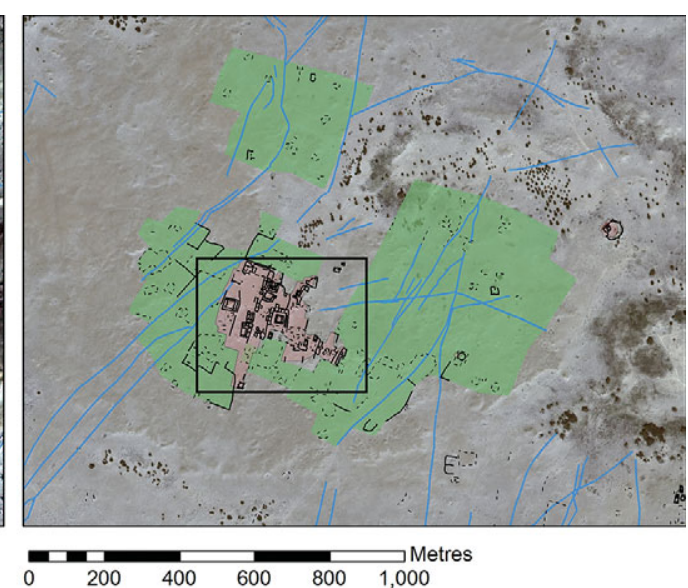

Figure 6. 2011 WorldView-2 image of HHG006-008: left) detail of the settlement; right) archaeological features in the vicinity.

and HHG008 to the south. Imported Roman ceramics were found across the site and an AMS date from HHG007 gives a probable third or fourth century AD date. The site is located on the edge of a large dried-out lake (salina) and to the south there are numerous underground water canals (foggaras) that would have brought water from up to $1.5 \mathrm{~km}$ away. Traces of garden walls and wells around the settlement suggest a field system of at least 60ha, but likely much larger in size. Some evidence was noted for carnelian working and metallurgy at this site. It seems to have a number of similarities with Qasr ash-Sharraba, but was substantially smaller, with a significantly reduced cultivation area (and by implication a smaller population).

(C) Antiquity Publications Ltd. 


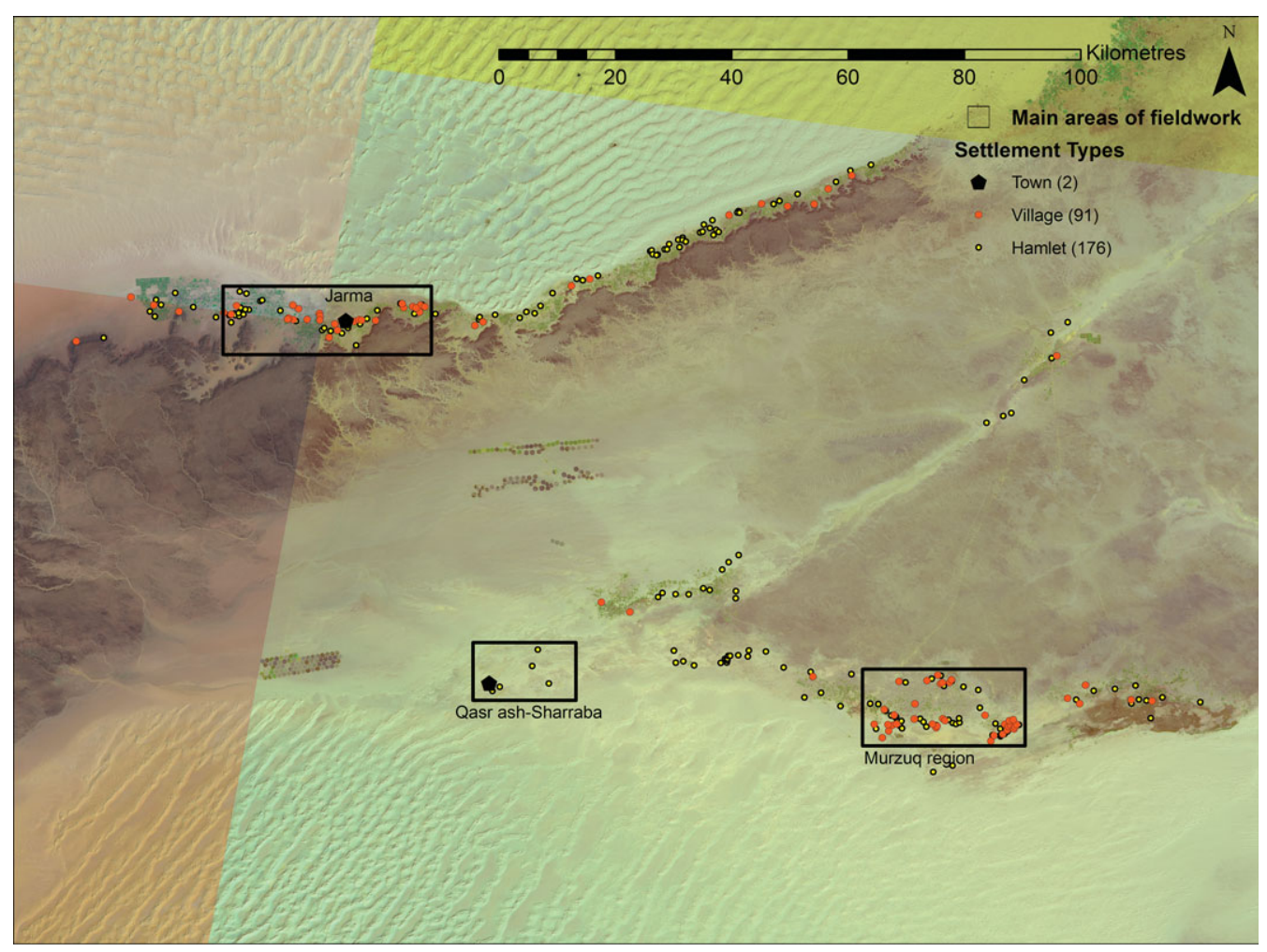

Figure 7. The distribution of Garamantian-period settlements in Fazzan. Landsat imagery courtesy of USGS.

\section{The settlement hierarchy in Garamantian times}

The newly discovered sites demonstrate that Fazzan as a whole must have been highly developed during the Garamantian period, with most of the population living in small urban- or village-scale settlements of sophisticated layout.

On present evidence (Figure 7) there was substantial expansion of village-type settlement clusters in the areas best suited for oasis cultivation. In at least two cases (Qasr ash-Sharraba and Jarma) we appear to be dealing with primary centres involving larger than average populations and seemingly fulfilling important administrative and economic functions for the surrounding area.

The clearer picture of Qasr ash-Sharraba in its landscape context leaves little doubt about its position at the top of a settlement hierarchy. It was at least twice the size of the next largest settlements in the Wadi Utba or Murzuq basin and appears to have had a substantial hinterland with satellite qsur and buildings. This was seven to eight times the size of agricultural areas attached to HHG001 and HHG006-008. Re-evaluating the Fazzan Project data, a similar pattern can now also be observed in the Wadi al-Ajal. Jarma, at around 7.5ha, stands out as almost double the size of the next largest contemporary settlement in the Wadi, GBD001 (a 4ha fortified enceinte and qasr). The smaller settlements around Old (C) Antiquity Publications Ltd. 
Jarma are a mixture of unfortified satellite villages in the close hinterland, with qsur and fortified villages found predominantly in more distant parts of the Wadi.

So far our work has explored in detail just two of the main oasis clusters that make up Fazzan. Further urban-scale sites may be expected in the virtually uncharted sub-regions of Zuwila or the Wadi ash-Shati. Additionally, HHG006-008 might be considered a village that was, by virtue of its size, on the cusp of urbanism, but with less evidence for trade and manufacturing than Qasr ash-Sharraba and Jarma. Without fuller excavation of these sites it is difficult to draw parallels for the style of urbanism, but building forms are reminiscent of both Roman North African and contemporary Nilotic towns. However, the presence of fortified compounds within the majority of settlements might better be considered to be part of a wider Maghrebian trend, albeit a Garamantian version. Similar contemporary structures (square compounds/towers, often with towers and/or ditches) are visible in the pre-desert at settlement sites such as Ghirza (Brogan \& Smith 1984). Security seems an obvious concern, and in all periods Fazzani settlements regularly incorporated elements of clustering, enclosing walls, towers and citadels. This likely reflects the importance of protecting harvests and land in a hyper-intensive agricultural regime. Yet we need not see the construction of so many fortifications as evidence of a period of decline or instability. Instead, the picture emerging from the dating of these structures is that they represent a peak in settlement numbers in the period around AD 300-500, when fortifications were the norm. On this evidence we now suggest a site hierarchy for Fazzan in the Garamantian period (Table 1).

\section{Discussion}

Instead of trying to match oasis towns to criteria determined for Mesopotamia and Mesoamerica, it is perhaps more useful to consider how they would have been perceived in their wider North African context. Roman Africa is famous for its $c .600$ well preserved cities, although fewer than 10 per cent were likely to have had over 5000 inhabitants or an area in excess of 25ha (Wilson 2011).

In the Roman province of Tripolitania, directly north of Fazzan, the largest cities covered more than 50ha at their zenith and would have dwarfed the urban sites of Fazzan. However, we should note that at Sabratha and Lepcis Magna both the underlying evidence of the Punic phase and the surviving Byzantine walls reflect much smaller settlements, close in size to the Garamantian towns. Smaller Romano-African towns (municipia and civitates) perhaps provide a better model. Gigthis is the prime example of this settlement type, with an area of 20ha (revised down from Mattingly's 1995 estimate of $c$. 50ha). It had a modest monumental centre with forum, basilica, baths and temples and a 'haphazard' urban layout. We can expand our portfolio by considering towns of neighbouring Africa Proconsularis (Table 2; Figure 8).

The Garamantian towns and the smaller Roman towns of Africa Proconsularis were hence of similar size. Would the Romans have considered these Saharan sites as urban? A strong case can be made that they had the character of urban centres rather than large villages. At Jarma there were public buildings in ashlar masonry and the massive walls of a possible qasr or citadel. The settlement was surrounded by numerous smaller sites and there were no sites of equal size elsewhere in the Wadi al-Ajal. Similarly, Qasr ash-Sharraba had a citadel and

(C) Antiquity Publications Ltd. 
Table 1. Site-type hierarchy in Garamantian Fazzan.

\begin{tabular}{|c|c|c|}
\hline Site type & Description & Example \\
\hline $\begin{array}{l}\text { Towns: large multi-hectare } \\
\text { urban conurbations, walled or } \\
\text { unwalled }\end{array}$ & $\begin{array}{l}\text { Large agglomerations with } \\
\text { several satellite villages, qsur } \\
\text { and/or buildings }\end{array}$ & $\begin{array}{l}\text { Qasr ash-Sharraba and } \\
\text { Jarma }\end{array}$ \\
\hline $\begin{array}{l}\text { Fortified villages: large villages } \\
\text { up to } 4 \text { ha with an outer } \\
\text { enceinte enclosing all or most } \\
\text { settlement and a single, } \\
\text { central qasr }\end{array}$ & $\begin{array}{l}\text { Independent substantial villages } \\
\text { or satellite villages in prime } \\
\text { agricultural locations }\end{array}$ & HHG001, GBD001 \\
\hline $\begin{array}{l}\text { Villages with qsur: large villages } \\
\text { of agglomerated settlement up } \\
\text { to 6ha (more commonly } \\
<4 \text { ha), lacking an outer } \\
\text { enceinte but with one to three } \\
\text { qsur }\end{array}$ & $\begin{array}{l}\text { Independent substantial villages } \\
\text { or satellite villages with focal } \\
\text { fortified building (qasr) }\end{array}$ & $\begin{array}{l}\text { HHG006-008, } \\
\text { GAT008-009, ELH003 }\end{array}$ \\
\hline $\begin{array}{l}\text { Open villages: settlements of } \\
\text { c. } 0.5-2 \text { ha lacking indication } \\
\text { of either qsur or surrounding } \\
\text { enceinte }\end{array}$ & $\begin{array}{l}\text { Medium-sized communities } \\
\text { with agricultural or industrial } \\
\text { functions, the only definite } \\
\text { example is clearly a satellite } \\
\text { settlement }\end{array}$ & GER002 (Saniat Jibril) \\
\hline $\begin{array}{l}\text { Isolated qsur: fortified buildings } \\
\text { without surrounding enceintes } \\
\text { and little or no associated } \\
\text { settlement }\end{array}$ & $\begin{array}{l}\text { Hamlet-sized communities, } \\
\text { normally satellites to larger } \\
\text { settlements or in marginal } \\
\text { agricultural locations }\end{array}$ & MAR001 \\
\hline $\begin{array}{l}\text { Isolated mudbrick buildings: } \\
\text { groups of one to three } \\
\text { buildings, normally found } \\
\text { within garden areas }\end{array}$ & Satellites to other settlements & $\begin{array}{l}\text { Structures in Sharraba } \\
\text { gardens }\end{array}$ \\
\hline $\begin{array}{l}\text { Isolated oval huts: temporary } \\
\text { camps found outside of the } \\
\text { agricultural zone }\end{array}$ & $\begin{array}{l}\text { Wide range of pastoral camps, } \\
\text { work areas for quarrying, } \\
\text { tomb construction, caravans? }\end{array}$ & TAG058 \\
\hline
\end{tabular}

two qsur within the settlement, and some urban planning. At both sites the large number of nearby cemeteries indicate a centre of population. At Jarma there is abundant evidence for wide-ranging trade links with the Mediterranean and it is perhaps significant that the surface quantities of Mediterranean imports at (unexcavated) Qasr ash-Sharraba far exceed what was observed at lesser centres in the Murzuq area. It seems fair to suggest that these were not just large agricultural villages but were major foci of political and economic power.

Similarly, in the medieval and Ottoman periods the only other settlements that reached town size were the successive capitals of Zuwila (20ha), Traghan and Murzuq (45ha). Although Murzuq retained its position until the Italian period, it was notably depopulated by the time it was visited by Europeans in the nineteenth century, with the southern quarter entirely abandoned and gardens within the city walls. Other settlements in these later periods were only of a few hectares in size.

In Fazzan we would suggest that 4 ha (perhaps around 400-800 inhabitants) represents the upper limit for a purely agricultural settlement that was reliant on wells or foggaras (C) Antiquity Publications Ltd. 
Table 2. Sizes of Garamantian and Roman cities.

\begin{tabular}{lc}
\hline Settlement & Size \\
\hline Jarma & 7.5-9ha \\
Byzantine Sabratha & 9ha \\
Qasr ash-Sharraba & $\mathbf{1 5 - 1 8 h a}$ \\
Byzantine Lepcis Magna & $18 \mathrm{ha}$ \\
Pheradi Maius & $18 \mathrm{ha}$ \\
Mistis & $19 \mathrm{ha}$ \\
Gigthis & $20 \mathrm{ha}$ \\
Thapsus & $23 \mathrm{ha}$ \\
\hline
\end{tabular}

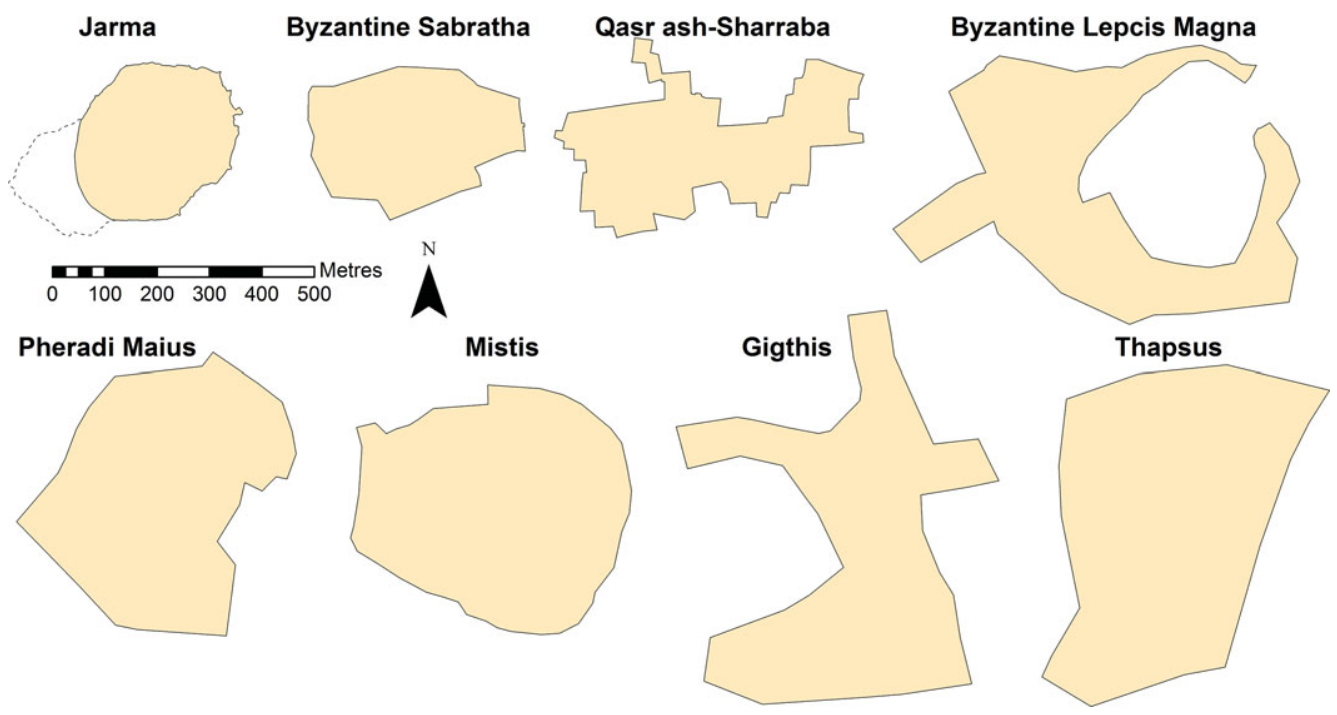

Figure 8. Size comparison of Garamantian and selected contemporary Roman cities.

for irrigation. Centres of around 7.5-10ha and above represent an urban element in the pre-modern settlement hierarchy. The harsh desert conditions constrain the emergence of larger nucleated centres. Fletcher (1995) suggests that maximum settlement area is a function of communication range and traffic capacity. The hyper-intensive farming of irrigated gardens may have increased traffic, whilst the restricted access to water and high summer temperatures effectively reduced the communication range far below that seen in temperate agricultural regimes (around 500m?). Urban centres, even of small size, placed increased stress on the ability of their inhabitants to feed themselves, and had to be sustained or supplemented through other means. The large urban settlements of Fazzan were not the consequence of particularly fertile locales, but places where substantial outside investment had been made to create a centre that had functions beyond farming. The most likely reasons behind this investment are undoubtedly control of trade routes or exercising of political authority. 


\section{Conclusions}

The capital-intensive costs of irrigated farming have constrained the self-sufficiency of most oases through time (see Scheele 2010: 284-88). Towns were unlikely to have developed in the Sahara on the basis of oasis agriculture alone and their sustainability was closely linked to the vagaries of Saharan trade. The fortunes of Jarma changed dramatically when trade routes shifted away from that town in the Islamic era (Mattingly forthcoming). In large areas of intensive oasis agriculture, it is likely that there would also be a related primary centre either in the oasis or closely connected to it. Oasis towns have traditionally had the characteristics of a relatively small area, hinterland and population, but with significant craft production and trade specialists. In this model, trade rather than agriculture created the additional surplus required to support the growth of the town, although there would probably be some agricultural (or water) surplus to support caravans. The town thus attracted and facilitated trade, and its wellbeing was intimately linked to its economic success. Islamic Ghadames, Ghat, Murzuq and Zuwila can be seen operating in this manner. At each of these, when trans-Saharan trade routes were disrupted, the cities stagnated and shrank in population (Eldblom 1968). In the Tuat oases there were food shortages and malnutrition when French colonial forces stopped all movement of trade goods (Scheele 2010).

External stimulus was required for an oasis city to develop successfully, and some even operated at an agricultural deficit. Capital investment may have come from another developed oasis city, but could also have been drawn from outside the desert region. In Islamic-era Fazzan, external northern and southern states developed new centres such as Zuwila, Traghan and Murzuq. Similarly, Mills (1993) has suggested that Roman period expansion within the Daklah oasis was a direct result of imperial interest. Our key conclusion is that the same socio-economic factors for urban growth and decline also applied to preIslamic Saharan society. It follows that the wellbeing of these desert towns could be just as profoundly affected by political and economic shifts as by environmental changes. A prime focus must now be to determine the conditions in which these settlements arose and fell, something for which further survey and excavation will be required.

Yoffee (2009: 282) describes cities as "not things or essences but points of entry into... what changed in the 'urban revolution'". The identification of Qasr ash-Sharraba and Old Jarma as the earliest urban societies in the central Sahara compels us to investigate what changed. It is not just their desert location that is remarkable, but that they fit comfortably alongside the contemporary urban societies that were present on the fringes of the Saharaas demonstrated on the Mediterranean coast, the Upper Nile and the Middle Niger delta. The discoveries call into question how isolated these different urbanised zones were from one another. This is not to suggest in any way that we should return to diffusionist models of towns and states in Saharan and sub-Saharan Africa. Rather, we suggest that towns were a necessary condition for the emergence of trans-Saharan connections and that this was happening across a wide space as early as the second half of the first millennium BC.

In the wider Saharan context, preliminary observations and reports suggest that there are remains of urban proportions in the Jufra and at Ghadames and the Nefzaoua oasis groups (respectively north and north-west of Fazzan). The small oasis of Ghat has produced remarkable evidence of Garamantian settlements, although none of urban scale or form (C) Antiquity Publications Ltd. 


\section{J. Mattingly \& M. Sterry}

(the largest site, Aghram Nadharif, is only 0.7ha; Liverani 2006). Together these give clear evidence of state-level activity in the north-eastern Sahara. Elsewhere the picture is more clouded. Excavations in Mali at Tadmakka (Nixon 2009) and Timbuktu (Insoll 1998) have provided little evidence of trans-Saharan trade before the late first millennium AD, yet we have no reason to assume that pre-Islamic centres would underlie those of Islamic date. It is all the more unfortunate that there has been so little research at more distant oases at Jado, Bilma and Dirkou in Niger and Tuat and Tamanrassat in Algeria given the archaeological potential for understanding the pre-Islamic Sahara. We have been aware for some time of towns in the western desert of Egypt (Siwa, Daklah, etc.), but those have tended to be seen as exceptional outposts of Nile Valley civilisations. The evidence presented here would suggest that we could equally consider these alongside other Saharan towns.

\section{Acknowledgements}

The mapping of Libyan desert settlements has been carried out through the Peopling the Desert Project funded by the Leverhulme Trust (F/00212/AL) and has been continued as part of the ERC-funded Trans-Sahara Project. Fieldwork in Libya took place as part of the work of the Fazzan Project and the Desert Migrations Project, with funding support from the Society for Libyan Studies. The detailed plan of Qasr ash-Sharraba was made possible by a satellite imagery grant provided by the GeoEye Foundation.

\section{References}

Austen, R.A. 2010. Trans-Saharan Africa in world history. Oxford: Oxford University Press.

Ayoub, M. 1967. Excavations in Germa: between 1962 to 1966. Tripoli: Ministry of Education.

Berggren, J.A. \& A. Jones. 2000. Ptolemy's Geography. An annotated translation of the theoretical chapters. Princeton (NJ): Princeton University Press.

Brogan, O. \& D.J. SMITH. 1984. Ghirza, a Libyan settlement in the Roman period (Libyan Antiquities Series 1). Tripoli: Department of Antiquities.

Childe, V.G. 1950. The urban revolution. Town Planning Review 21(1): 3-17.

Cowgill, G.L. 2004. Origins and development of urbanism: archaeological perspectives. Annual Review of Anthropology 33: 525-49.

DANIELS, C.M. 1989. Excavation and fieldwork amongst the Garamantes. Libyan Studies 20: 45-61.

Eldblom, L. 1968. Structure foncière: organisation et structure sociale. Lund: Uniskol.

FLETCHER, R. 1995. The limits of settlement growth: a theoretical outline. Cambridge: Cambridge University Press.

INSOLL, T. 1998. Archaeological research in Timbuktu, Mali. Antiquity 72: 413-17.

Liverani, M. (ed.). 2006. Aghram Nadarif. A Garamantian citadel in the Wadi Tannezzuft. Florence: All'Insegna del Giglio.
LYDON, G. 2009. On trans-Saharan trails: Islamic law, trade networks and cross-cultural exchange in nineteenth-century western Africa. Cambridge: Cambridge University Press.

Mattingly, D.J. 1995. Tripolitania. London: Routledge.

- (ed.). 2003. The archaeology of Fazzan. Volume 1: synthesis. London: Society for Libyan Studies.

- 2006. The Garamantes: the first Libyan state, in D. Mattingly, S. McLaren, E. Savage, Y al-Fasatwi \& K. Gadgood (ed.) The Libyan desert: natural resources and cultural heritage: 189-204. London: Society for Libyan Studies.

- (ed.). 2007. The archaeology of Fazzan. Volume 2: site gazetteer, pottery and other finds. London: Society for Libyan Studies.

- (ed.). 2010. The archaeology of Fazzan. Volume 3: excavations carried out by C.M. Daniels. London: Society for Libyan Studies.

- (ed.). Forthcoming. The archaeology of Fazzan. Volume 4: survey and excavations at Old Jarma (Ancient Garama) carried out by C.M. Daniels (1962-69) and the Fazzān Project (1997-2001). London: Society for Libyan Studies.

Mattingly, D.J. \& K. MacDonald. 2013. Early African cities, in P. Clark (ed.) The Oxford handbook of the city in history: 66-82. Oxford: Oxford University Press.

McIntosh, R.J. 2005. Ancient Middle Niger: urbanism and the self-organizing landscape. Cambridge: Cambridge University Press.

(C) Antiquity Publications Ltd. 
McInTosh, S. (ed.). 1999. Beyond chiefdoms: pathways to complexity in Africa. Cambridge: Cambridge University Press.

MiLls, A.J. 1993. The Dakhleh oasis colombarium farmhouse. Bulletin de la Societé archéologique d'Alexandrie 45: 192-98.

Morley, N. 2011. Cities and economic development in the Roman Empire, in A. Bowman \& A. Wilson (ed.) Settlement, urbanization, and population: 143-60. Oxford: Oxford University Press.

NIXON, S. 2009. Excavating Essouk-Tadmakka (Mali): new archaeological investigations of early Islamic trans-Saharan trade. Azania: Archaeological Research in Africa 44(2): 217-55.

Rackham, H. 1938. Pliny: Natural History, Volume II, Books 3-7 (Loeb Classical Library). Cambridge (MA): Harvard University Press.

SCHEELE, J. 2010. Traders, saints, and irrigation: reflections on Saharan connectivity. The Journal of African History 51(3): 281-300.

SMITH, A.T. 2003. The political landscape: constellations of authority in early complex polities. Los Angeles: University of California Press.

SMITH, M. (ed.). 2003. The social construction of ancient cities. Washington, D.C.: Smithsonian Institution Press.
SMITH, M.E. 2009. V. Gordon Childe and the urban revolution: an historical perspective on a revolution in urban studies. Town Planning Review 80: 2-29.

Sterry, M. \& D. MATtingly. 2011. DMP XIII: reconnaissance survey of archaeological sites in the Murzuq area. Libyan Studies 42: 89-116.

Sterry, M., D. Mattingly \& T. Higham. 2012. Desert Migrations Project XVI: radiocarbon dates from the Murzuq region, southern Libya. Libyan Studies 43: 137-47.

TALBERT, R.J.A. (ed.). 2000. Barrington atlas of the Greek and Roman world. Princeton (NJ): Princeton University Press.

Wilson, A. 2011. City sizes and urbanization in the Roman Empire, in A. Bowman \& A. Wilson (ed.) Settlement, urbanization, and population: 161-95. Oxford: Oxford University Press.

Wilson, A. \& D. MatTingly. 2003. Irrigation technologies: foggaras, wells and field systems, in D.J. Mattingly (ed.) The archaeology of Fazzan. Volume 1: synthesis: 235-78. London: Society for Libyan Studies.

YOFFE, N. 2005. Myths of the archaic state: evolution of the earliest cities, states and civilizations. Cambridge: Cambridge University Press.

- 2009. Making ancient cities plausible. Reviews in Anthropology 38: 264-89.

Received: 1 August 2012; Accepted: 28 September 2012; Revised: 26 October 2012

(C) Antiquity Publications Ltd. 